Ethos: Jurnal Penelitian dan Pengabdian kepada Masyarakat, Vol 8, No.2, Juni 2020: 191-198

\title{
Pelatihan Pengelolaan Media Sosial Kampung Biru Arema Sebagai Media PROMOSI
}

\section{${ }^{1}$ Tantri Refa Indhiarti, ${ }^{2}$ Yana S Manipuspika, ${ }^{3}$ Emy Sudarwati}

\author{
1,2,3 Universitas Brawijaya, Malang, Jawa Timur, Indonesia \\ email: ${ }^{1}$ tantri.refa@ub.ac.id
}

\begin{abstract}
This community service is carried out to find out and revitalize promotional activities in one of the thematic tourist villages in Malang City as well as the fostered partners of the Faculty of Cultural Sciences, Universitas Brawijaya (FIB UB), namely Kampung Biru Arema (KBA). Being one of the new tourist destinations, KBA is making efforts to develop tourism potential by increasing online promotion. However, in the process, there are several obstacles such as the need to increase awareness of the local community to jointly promote digital tourism opportunities. Thus, to find out data on how far and what the tourism promotion efforts by the KBA community are, several techniques such as interviews, observation, socialization, training and revitalization were conducted. The results of the activities showed that the promotion carried out by KBA managers was by using social media in the form of Instagram and Youtube. In this case, the results of community service activities can increase the knowledge of the KBA community on the importance of being skilled in managing digital promotions and awareness of the sustainability of tourism promotion and encouraging local communities to create and add tourism products and services.

Keywords: Kampung Biru Arema, Social Media, Training, Promotion
\end{abstract}

\begin{abstract}
Abstrak. Pengabdian kepada masyarakat ini dilakukan untuk mengetahui dan merevitalisasi kegiatan promosi salah satu kampung wisata tematik di Kota Malang sekaligus sebagai mitra binaan Fakultas Ilmu Budaya Universitas Brawijaya (FIB $U B)$ yaitu Kampung Biru Arema (KBA). Menjadi salah satu tujuan wisata baru, KBA sedang melakukan usaha untuk mengembangkan potensi wisata dengan meningkatkan promosi secara daring. Akan tetapi, dalam prosesnya, terdapat beberapa kendala seperti perlu ditingkatkannya kesadaran masyarakat setempat untuk ikut bersama-sama mempromosikan peluang wisata secara digital. Dengan demikian, untuk mengetahui data mengenai seberapa jauh dan apa saja usaha promosi wisata oleh masyarakat KBA, beberapa teknik seperti wawancara, observasi, sosialisasi, pelatihan dan revitalisasi dilakukan. Hasil kegiatan menunjukkan bahwa promosi yang dilakukan oleh pengelola KBA yaitu dengan menggunakan sosial media berupa Instagram dan Youtube. Dalam hal ini, hasil kegiatan pengabdian dapat menimgkatkan pengetahuan masyarakat KBA akan pentingnya terampil dalam pengelolaan promosi digital dan kesadaran atas keberlanjutan promosi wisata serta mendorong masyarakat setempat untuk menciptakan dan menambah produk dan jasa wisata.
\end{abstract}

Kata Kunci: Kampung Biru Arema, Media Sosial, Pelatihan, Promosi

\section{Pendahuluan}

Segala bentuk kehidupan manusia saat ini tidak dapat dipisahkan dari pentingnya teknologi yang apabila digunakan dengan bijak dapat membawa bentuk kehidupan yang lebih berkembang. Hal ini salah satunya dapat dilihat dari kemajuan teknologi dan juga dukungan investasi yang membuat perubahan dalam dunia pariwisata. Dengan adanya teknologi tersebut, manajemen pelayanan dan promosi wisata menjadi lebih cepat. Hal ini 
berkaitan dengan perlunya sektor wisata mempersiapkan diri untuk menghadapai pasar bebas ASEAN yang telah dimulai pada tahun 2015 di mana perkembangan dunia wisata dihadapkan pada kompetisi yang semakin ketat.

Seiring meningkatnya kebutuhan masyarakat untuk berwisata, Indonesia telah mewujudkan kampung wisata tematik. Salah satunya yaitu Kampung Biru Arema (KBA) di kota Malang yang diresmikan pada 6 Februari 2018. Sebagai kampung wisata baru dan terletak sejajar dengan kampung wisata tematik lainnya yaitu Kampung Warna Warni dan Kampung Tridi, KBA perlu memikirkan media informasi yang dapat menyebarkan potensi wisatanya dengan daya jangkau yang cepat dan luas. Hal ini dikarenakan promosi merupakan kegiatan penyebaran informasi untuk disampaikan pada calon wisata dan dapat menentukan perkembangan wisata (Hermawan, 2012).

Salah satu media informasi yang dapat menjawab tantangan kompetensi wisata saat ini yaitu media sosial. Menurut Permenpan Nomor 83 tahun 2012 mengenai Pedoman Pemanfaatan Media Sosial Instansi Pemerintah, penggunaan media sosial dapat membentuk dan mendukung cara baru dalam berkomunikasi, berinteraksi dan berkolaborasi. Hal ini terlihat pada penelitian oleh Hamzah (2013) yang mengidentifikasi potensi media sosial sebagai sarana promosi interaktif bagi wisata di Indonesia. Dalam penelitian ini dijelaskan bahwa seseorang mempelajari sesuatu melalui proses imitasi di mana perilaku pengguna media sosial lainnya dapat memengaruhi keputusannya untuk mengunjungi desinasi wisata. Dengan melihat adanya unsur penting dari pemilihan media yang turut memengaruhi keberhasilan sebuah promosi untuk destinasi wisata pada penelitian sebelumnya, pengabdian masyarakat ini difokuskan pada pelatihan pengelolan media sosial yang digunakan KBA sebagai sarana promosi potensi wisata. Fokus kegiatan ini dipilih karena promosi digital KBA belum berjalan secara maksimal dalam hal tidak banyak konten media yang dikelola oleh masyarakat KBA sendiri yang mencerminkan produk dan jasa setempat.

Melihat perkembangan usaha promosi wisata di Kampung Biru Arema, promosi masih dilakukan dengan cara yang konvensional melalui berita mulut ke mulut dan bahkan hampir tidak didapati usaha promosi sama sekali. Padahal, salah satu poin penting terkait manajemen informasi yaitu penyebaran informasi organisasi kepada masyarakat luas (Muhammad dkk, 2019). Sebagai destinasi wisata yang baru didirikan, KBA merupakan objek yang unik yang menyajikan suatu bentuk kehidupan alami bermasyarakat dan tidak hanya berdasar pada pewarnaan biru. Akan tetapi, masih terdapat kendala dalam pengelolaan media promosi tersebut. Dengan demikian, kegiatan pengabdian ditujukan untuk merevitalisasi media sosial yang telah digunakan yaitu Instagram untuk mendukung warga masyarakat KBA dalam memberikan berbagai informasi kepada calon wisatawan mengenai berbagai kegiatan yang mencerminkan budaya masyarakat setempat dan potensi wisata baik tempat, barang maupun jasa.

\section{Metode}

Untuk memperoleh informasi secara langsung mengenai bagaimana pemanfaatan media sosial untuk memasarkan produk dan jasa di KBA, tahapan diskusi dilakukan dengan jajaran kelompok sadar wisata (Pokdarwis), Karang Taruna, dan perangkat RW 5 di KBA sebagai mitra binaan. Pada forum diskusi tersebut, informan bebas untuk memberikan informasi apa saja karena tim ingin 
mengetahui lebih dalam bagaimana masyarakat KBA mempromosikan dan membuat kegiatan promosi untuk menjual produk dan jasa. Selanjutnya, tahapan observasi dilakukan dengan menemui pihak terkait sebagai instansi mitra pengelola KBA. Dalam hal ini, tim menemui Kepala Dinas Kebudayaan dan Pariwisata Kota Malang untuk membuat kesepakatan MoU tentang potensi KBA yang perlu dibantu pengembangannya.

Setelah mengetahui sarana promosi wisata yang digunakan oleh masyarakat KBA, tim melakukan sosialisasi yang bertempat di balai serbaguna KBA untuk memberikan pemahaman tentang arti pentingnya media sosial dalam era digital informasi global bagi pengembangan kehidupan sosial, budaya, dan ekonomi masyarakat KBA. Sebagai tahapan akhir, bersama dengan pengelola media sosial KBA, revitalisasi dilakukan atas fitur-fitur mana saja yang harus dimasukkan dalam media sosial. Selain itu, masyarakat KBA membuat video pendek mengenai kawasan setempat. Dalam hal ini, konten video dan Instagram dibahas bersama dengan tim pengabdian masyarakat sebagai bentuk evalusi.

\section{Hasil dan Pembahasan}

Dalam pelaksanaan kegiatan pengabdian kepada masyarakat $(\mathrm{PkM}) \mathrm{di}$ Kampung Biru Arema (KBA), tim menemukan dua permasalahan yaitu, media apa yang digunakan dalam kegiatan promosi potensi wisata dan bagaimana kegiatan promosi tersebut dapat direvitalisasi sesuai dengan perkembangan kebutuhan KBA. Oleh karena itu, tujuan kegiatan ini adalah meningkatkan pengetahuan dan keterampilan masyarakat KBA mengenai pentingnya mengelola media promosi secara mandiri dan berkelanjutan.

\section{Kegiatan Promosi Wisata di Kampung Biru Arema}

Setelah dilakukan wawancara dan pengamatan langsung, diketahui bahwa media yang digunakan untuk mempromosikan wisata KBA adalah media sosial. Media ini dipilih oleh KBA karena memiliki karakteristik interaktif yang tidak bisa ditemukan oleh media tradisional seperti brosur. Karakter interaktif dalam konteks ini menunjukkan adanya kemampuan bagi penggunanya, baik masyarakat KBA maupun calon wisatawan untuk terlibat secara langsung dan menambah gambar, video, atau teks yang mereka akses. Di samping itu, proses komunikasi yang terjadi tidak bersifat satu arah, melainkan dua arah di mana pengguna dapat mengajukan pertanyaan, menjawab pertanyaan dan melakukan proses jual beli.

Pemasaran interaktif yang dilakukan di KBA yaitu Instagram yang di dalamnya berisi sedikit sekali informasi yang dapat wisatawan temukan mengenai lokasi, kontak yang bisa dihubungi, peta wisata, dan beragam potensi wisata. Berikut ini adalah kutipan Instagram KBA sebelum dilakukan kegiatan PkM:

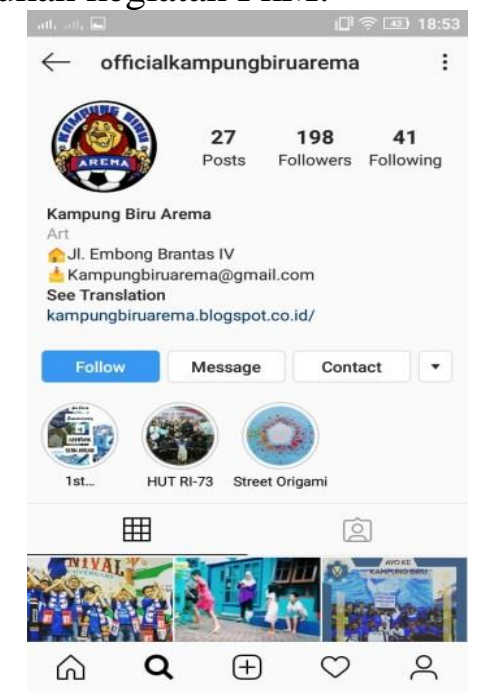

Gambar 1. Instagram KBA sebelum Kegiatan PkM

https://doi.org/10.29313/ethos.v8i2.5413 
Seperti yang terlihat dalam Gambar 1, Instagram belum dimanfaatkan secara keseluruhan mengingat post foto dan jumlah follower yang sedikit. Hal ini dapat disebabkan oleh nama Instagram yang panjang, yakni officialkampungbiruarema. Selain itu, meskipun di Instagram tersebut dicantumkan blog KBA, blog tersebut tidak aktif. Hal ini diperburuk dengan banyaknya post foto dengan tagar\#kampungbiruaremayang tidak dapat bersinergi dengan nama Instagram KBA, sehingga banyak foto yang menunjukkan potensi wisata KBA tidak tersorot oleh calon wisatawan seperti terlihat pada Gambar 2

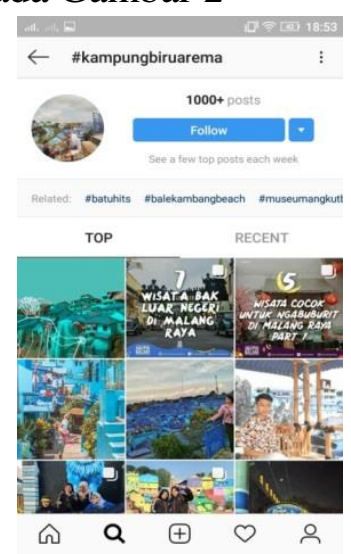

\section{Gambar 2. Hashtag untuk KBA}

Kegiatan promosi yang semestinya dilakukan dengan porsi lebih banyak oleh masyarakat KBA sendiri, justru dilaksanakan oleh pihak luar yaitu wisatawan yang pernah berkunjung dan portal pemberitaan nasional dan asing. Hal ini dapat dilihat pada gambar 4.3. Begitu pula sarana video dalam kanal youtube digunakan oleh wisatawan untuk menunjukkan pengalaman mereka berkunjung di KBA (Gambar 4.4).

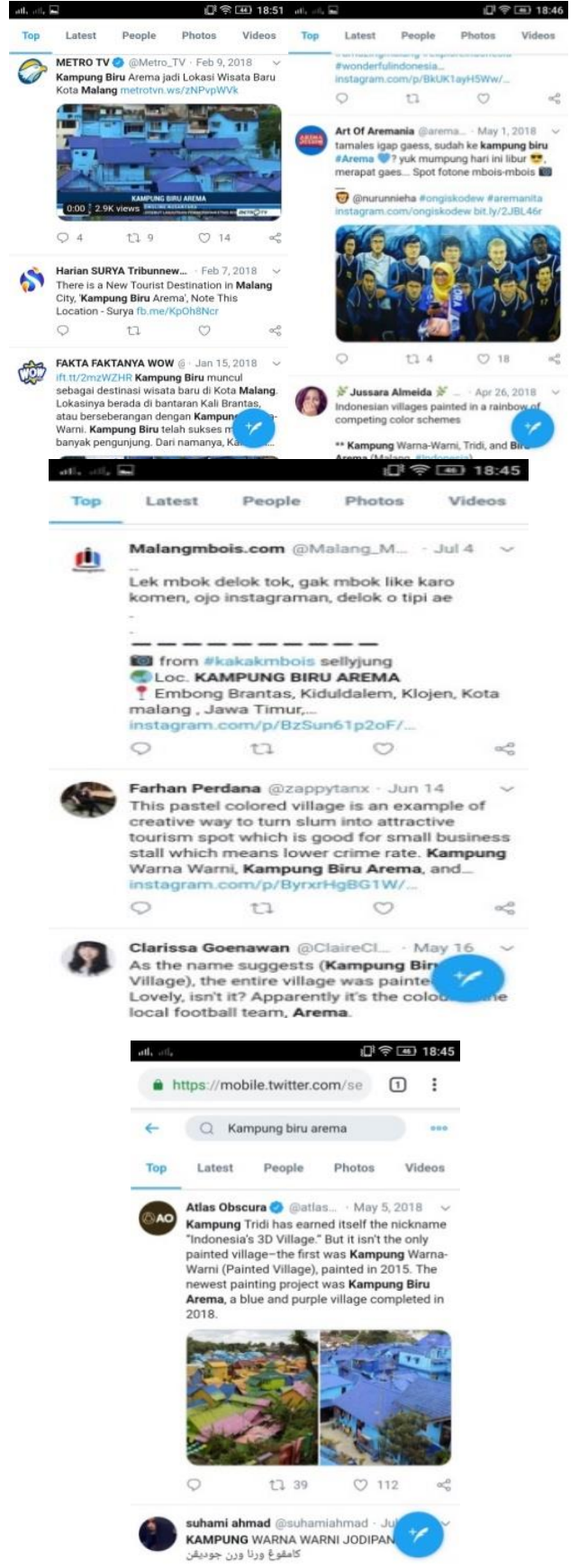

Gambar 3. Kutipan Ulasan oleh

Wisatawan dan Portal Berita mengenai KBA 


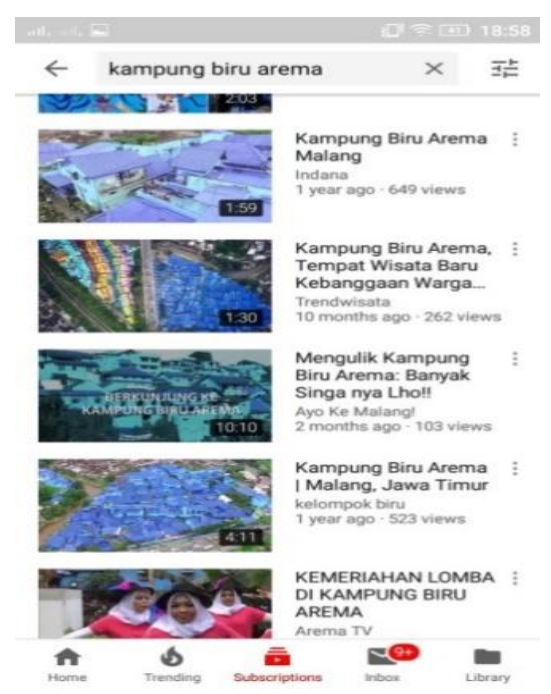

Gambar 4. Kanal Youtube yang Berkaitan dengan KBA

Dari berbagai media sosial tersebut, dapat diketahui bahwa meskipun banyak foto dan video yang ditayangkan untuk merepresentasikan KBA, tidak banyak foto dan video yang menunjukkan potensi wisata KBA secara keseluruhan. Dengan memanfaatkan sarana promosi interaktif tersebut, KBA seharusnya dapat secara rutin dan berkesinambungan untuk membuat status dan mengunggah foto kegiatan yang dilakukan di wilayah KBA. Selain itu potensi wisata KBA yang sekiranya belum dikenal luas juga dapat dipromosikan melalui Instagram maupun kanal youtube tersebut. Untuk mengisi bagian media promosi dalam bentuk daring yang belum sepenuhnya digunakan, masyarakat KBA merevitalisasi media sosial Instagram.

\section{Revitalisasi Media Sosial Kampung Biru Arema}

Untuk mengawali kegiatan revitalisasi media sosial, tim terlebih dahulu mengadakan kegiatan sosialisasi kepada masyarakat KBA mengenai pentingnya mengetahui apa saja potensi wisata yang dimiliki dan bagaimana mempromosikannya.

\section{Sosialisasi Pentingnya Media Promosi Potensi Wisata}

Kegiatan sosialisasi pada masyarakat KBA berupa penyampaian materi oleh seorang pakar branding kampung wisata di Jawa Timur dan juga sebagai pendiri Jagoan Indonesia. Dalam kegiatan tersebut disampaikan bahwa sebelum suatu destinasi wisata mempromosikan potensi wisata, perlu diperhatikan komponen pengembangan destinasi pariwisata, yaitu objek daya tarik wisata, aksesibilitas wisata, amenitas, dan ancillary service.

Dalam hal objek daya tarik wisata, sumber kepariwisataan dapat berupa 1) objek alami, seperti gunung, danau, pantai, atau bukit, 2) atraksi wisata budaya, berupa arsitektur rumah tradisional, situs arkeologi, seni dan kerajinan, ritual, festival, kehidupan masyarakat sehari-hari, keramahtamahan, atau makanan, dan 3) atraksi buatan, seperti acara olahraga, acara musik, pameran, atau wisata belanja. Di samping itu, objek wisata tersebut juga harus dilengkapi dengan komponen aksesibilitas berupa sarana untuk mempermudah wisatawan mencapai destinasi wisata terkait yang dapat berupa petunjuk arah, waktu yang dibutuhkan untuk sampai di destinasi wisata atau transportasi jenis apa saja untuk menuju lokasi wisata. Sebagai tambahan, komponen amenitas juga tidak boleh dilupakan. Amenitas dapat berupa rangkaian fasilitas untuk menunjang akomodasi wisata, yaitu tempat penginapan, ketersediaan makanan dan minuman atau tempat belanja. Komponen terakhir yaitu ancillary service yang mencakup fasilitas pendukung kegiatan wisata, seperti bank, ATM atau rumah sakit.

Dalam kegiatan ini, beberapa tokoh masyarakat seperti ketua Pokdarwis dan bendahara RW menyampaikan bahwa sebenarnya KBA telah memiliki semua komponen 
pengembangan kampung wisata tersebut, seperti objek wisata yang berupa buatan, fasilitas utama dan pendukung dan letak yang strategis. Namun demikian, karena kurangnya kesadaran masyarakat untuk mengelola KBA, seperti media promosi daring yang tidak berjalan dan ketidaktahuan bahwa kegiatan di masyarakat dapat dijadikan bahan promosi, destinasi wisata KBA mengalami masa kekosongan. Untuk mengatasi hal ini, tim pegabdian mengusulkan dibuatnya bank dokumen dengan memanfaatkan flash disc yang dapat menampung seluruh bukti kegiatan masyarakat KBA. Berikut ini beberapa contoh kegiatan oleh masyarakat KBA yang dapat ditampilkan dalam Instagram:

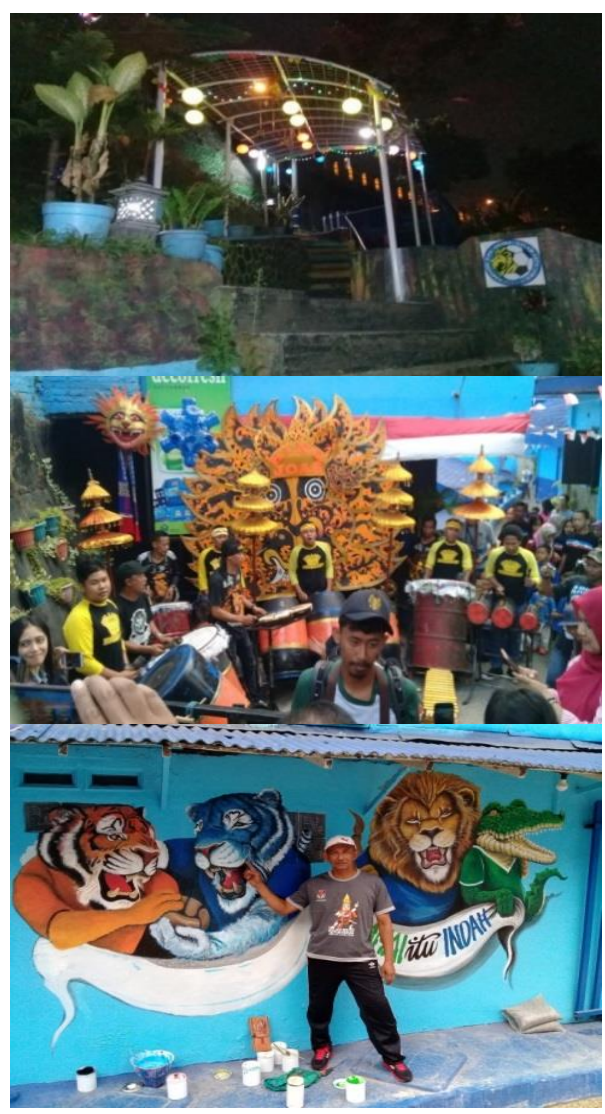

Gambar 5. Potensi Wisata KBA sebagai Bahan Promosi

\section{Pelatihan Promosi Wisata Kampung Biru Arema}

Setelah melaksanakan sosialisasi akan pentingnya pengembangan dan promosi wisata, tim melaksanakan pelatihan promosi wisata karena hal ini berkaitan erat dengan kegiatan komunikasi dan publikasi untuk membangun citra KBA. Hal ini dilakukan untuk mengakomodasi keinginan wisatawan yang dalam memutuskan destinasi wisata mana yang akan dikunjungi dapat dipengaruhi oleh citra yang dibangun misalnya oleh pemberitaan media, film, atau gambar. Dengan demikian, untuk membekali masyarakat KBA mengenai media promosi daring, beberapa hal yang terkait dengan hal itu, seperti definisi dan jenis media sosial yang dapat digunakan untuk promosi dipaparkan. Dalam pelatihan ini, pemateri memberikan penguatan bahwa sebenarnya telah ada media promosi oleh masyarakat KBA sendiri dan memberikan fokus pada aspek wisata berbasis kearifan lokal. Pada sesi ini, masyarakat juga diberikan wawasan mengenai bagaimana menjaga media sosial Instagram KBA agar terus aktif dengan memberikan muatanmuatan yang berkelanjutan.

\section{Revitalisasi Media Promosi KBA}

Melihat adanya beberapa kekosongan dalam media promosi potensi wisata KBA, setelah memperoleh penyuluhan dan sosialisasi, masyarakat KBA melakukan beberapa revitalisasi media sosial yang digunakan, yaitu Instagram. Tahapan revitalisasi ini meliputi:

a. Mengubah nama Instagram KBA dari officialkampungbiruarema menjadi kampungbiruarema.

Hal ini dilakukan agar ulasan dalam bentuk foto dan video KBA dengan tagar \#kampungbiruarema dapat bersinergi dengan nama Instagram 
tersebut. Perubahan tersebut berdampak dari banyaknya foto dari wisatawan yang berkunjung di KBA dalam tagar tersebut yang sebelumnya bagian 'tagged' ini tidak berisi konten apapun.

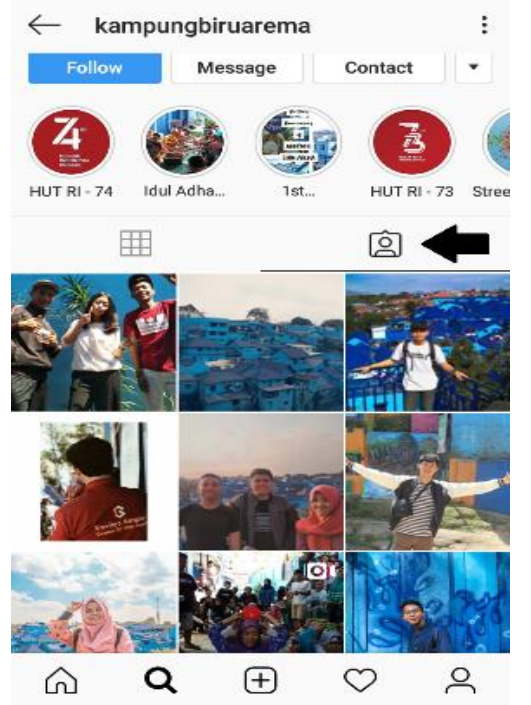

\section{Gambar 6. Foto-foto dengan Taggar \#kampungbiruarema sudah Berintegrasi}

b. Masyarakat KBA untuk membuat video pendek mengenai potensi wisata.

Jika sebelum pelaksanaan PkM, video yang berkaitan dengan KBA disampaikan oleh wisatawan yang pernah berkunjung, kali ini video dibuat sendiri oleh masyarakat KBA untuk menunjukkan potensi yang dimiliki. Kanal tersebut dapat dikunjungi dengan menggunakan alamat daring, yaitu https://youtu.be/XZUhHhPct3A. Dalam video tersebut, ulasan atas KBA tidak lagi bersifat sangat individual karena dibuat oleh wisatawan, tetapi inklusif dengan tetap memerhatikan komponen wisata yang ada.

c. Masyarakat mengisi Instagram dengan kegiatan-kegiatan KBA secara teratur.

Melalui kegiatan PkM ini, masyarakat kembali mendapatkan semangat untuk mengembangkan kampung wisatanya. Hal tersebut dapat diketahui dari jumlah story highlight yang bertambah, seperti 'HUT RI 74' dan 'Idul Adha'. Hal ini juga menunjukkan bahwa masyarakat setempat telah mendayagunakan gawai pintar untuk kepentingan KBA dengan bertambahnya unggahan foto di Instagram.

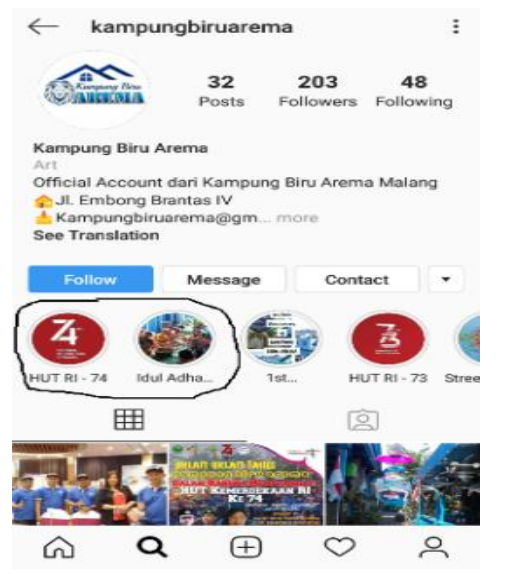

\section{Gambar 7. Bertambahnya Story Highlight Instagram KBA}

\section{Kesimpulan dan Saran}

Masyarakat KBA sebagai peserta pelatihan dalam pengelolaan media sosial mendapatkan manfaat mengenai meningkatnya kesadaran untuk mengelola media Instagram dan Youtube secara berkelanjutan dengan mengisi konten yang berkaitan dengan berbagai aktifitas sosial kemasyarakatan setempat. Hal ini dapat dilihat dari bertambahnya konten sosial dan jumlah pengunjung di KBA.

Karena media sosial tersebut telah direvitalisasi oleh masyarakat KBA sendiri, kegiatan promosi atas produk dan jasa KBA dapat dilakukan dengan lebih baik. Tagar yang telah diperbarui juga akan bisa tersinergikan dengan fotofoto maupun video yang di post oleh wisatawan yang berkunjung ke KBA sehingga KBA akan semakin dikenal luas.

Dengan demikian, tim menyarankan agar masyarakat KBA senantiasa menjaga keberlanjutan dalam kegiatan promosi produk dan jasa secara 
digital. Hal-hal sehari-hari masyarakat yang dirasa menarik pun dapat difoto kemudian ditayangkan di akun Instagram. Video kegiatan tahunan juga dapat ditayangkan di akun KBA untuk lebih mempromosikan Kampung Biru Arema di khalayak luas.

Selain itu, terdapat juga saran untuk kegiatan pengabdian selanjutnya yaitu melakukan pelatihan penggunaan media berbasis daring untuk mendata bidang usaha apa saja yang dilakukan masyarakat KBA. Dengan begitu, calon wisatawan dapat mengetahui seluruh informasi usaha yang ada di KBA sekaligus melakukan wisata virtual.

\section{DAFTAR PUSTAKA}

Biro Analisa Anggaran dan Pelaksanaan APBN. http://www.dpr.go . id/doksetjen /dokumen/biroapbn- apbn-Menjadikan-

Pariwisata-Sebagai-Sektor-

Unggulan-Penghasil- Devisa1433409452.pdf. (diakses 05 Agustus 2019).

Kotler, Phillip dan Keller, Kevin Lane. (2009).Manajemen Pemasaran Jilid 2. Jakarta: Airlangga.

Hamzah, Yeni Imaniar. (2013). Potensi

Media Sosial sebagai Sarana Promosi Interaktif Bagi Pariwisata Indonesia. Pusat Penelitian dan Pengembangan Kebijakan Kepariwisataan Kementerian Pariwisata dan Ekonomi Kreatif. Hal 1-9.

Hermawan, Agus. (2012). Komunikasi Pemasaran. Jakarta. Erlangga.

Muhammad, Fadlan, M., Hafid, M., Fahreza, M. I. (2019). Pengembangan Website Profile PMI Kota Tarakan sebagai Sarana Keterbukaan Informasi Publik. Ethos: Jurnal Penelitian dan Pengabdian kepada Masyarakat, 8(1). 132-138
Peraturan Menteri Pemberdayaan Aparatur Negara dan Reformasi Birokrasi (Permenpan)

Nomor 83 tahun 2012 tentang Pedoman Pemanfaatan Media Sosial Instansi Pemerintah. Jakarta. http://disparbud.malangkab.go.id (Diakses pada 21 Agustus 2019) 